\title{
Recent Advances in Detection of Ochratoxin-A
}

\author{
Ajeet Kaushik $^{1^{*}}$, Sunil K. Arya ${ }^{2}$, Abhay Vasudev ${ }^{3}$, Shekhar Bhansali ${ }^{1^{*}}$ \\ ${ }^{1}$ Bio-MEMS and Microsystems Lab, Department of Electrical and Computer Engineering, \\ Florida International University, Miami, USA \\ ${ }^{2}$ Bioelectronics Program, Institute of Microelectronics, A*STAR (Agency for Science, Technology and Research), 11 Science \\ Park Road, Singapore Science Park II, Singapore 117685, Singapore \\ ${ }^{3}$ Department of Biomedical Engineering, Florida International University, Miami, USA \\ Email: *ajeet.npl@gmail.com, ${ }^{*}$ sbhansa@fiu.edu
}

Received December 7, 2012; revised January 19, 2013; accepted January 27, 2013

\begin{abstract}
Ochratoxin-A [7-(L- $\beta$-phenylalanylcarbonyl)-carboxyl-5-chloro-8-hydroxy-3,4-dihydro-3R-methyl-isocumarin, OTA] is a common food contaminant mycotoxin that enters the human body through the consumption of improperly stored food products. Upon ingestion, it leads to immuno-suppression and immuno-toxicity. OTA has been known to produce nephrotoxic, teratogenic, and carcinogenic activity (via oxidative DNA damage) in several species. This review introduces potentials of electrochemical biosensor to provide breakthroughs in OTA detection through improved selectivity and sensitivity and also the current approaches for detecting OTA in food products.
\end{abstract}

Keywords: Biopolymer; Mycotoxins; Ochratoxin-A; Chitosan; Organic-Inorganic Hybrid Nanocomposite; Biosensors

\section{Introduction}

Mycotoxins are secondary metabolites produced by microscopic (micromycetes) and macroscopic (macromycetes) fungi which can contaminate food crop, or entire food crops, throughout the food chain. The toxic effects of these metabolites in mamals (including humans) is known as mycotoxicosis [1,2]. Figure 1 describes the various factors involved in mycotoxicosis. These factors lead to the production of fungal toxins i.e., mycotoxin. Fungal toxins are produced by species within the genera Fusarium, Aspergillus, and Penicillium, which frequently occur in crops or during storage of food [1]. These mycotoxins have deleterious effect on agricultural productivity, human health (including carcinogenesis, immune suppression, teratogenicity), growth retardation, and animal toxicities including the possible carry-over of mycotoxins or their metabolites into the human food chain [1].

Mycotoxins can appear in the food chain from infected crop, either by direct human consumption or through the use of livestock feed (Figure 2).

The high incidence of human food contamination with mycotoxins has led a research effort in the areas of mycotoxicology to study its biochemical mode of action, implications on human health, and development of analytical tools for quantitative and qualitative analysis of these toxins in human food [3-5]. Various techniques used for the detection of mycotoxins are summarized in Table 1 with their advantage and drawbacks.

${ }^{*}$ Corresponding authors.

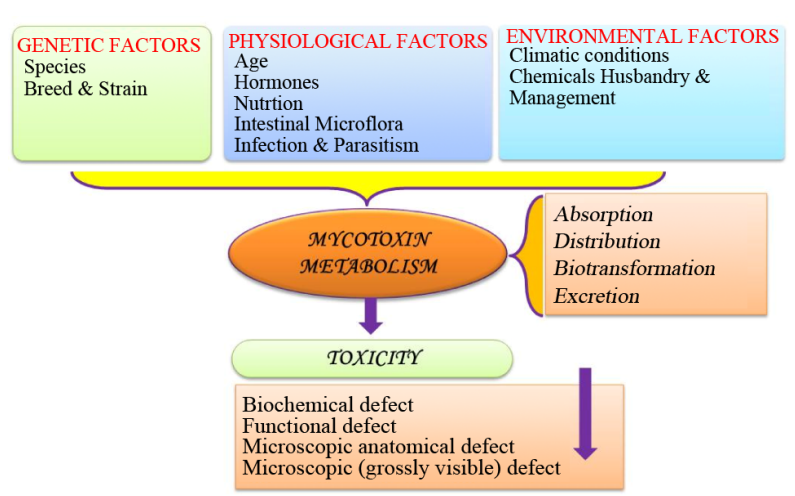

Figure 1. Representation of mycotoxicosis.

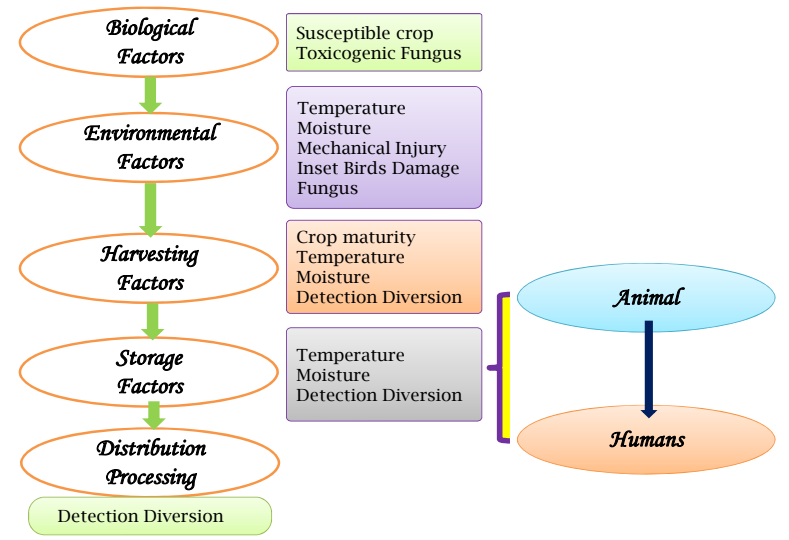

Figure 2. Factors affecting mycotoxin occurrence in the food and animal feed chains. 
Table 1. Analytical methods used to detect mycotoins.

\begin{tabular}{|c|c|c|}
\hline Analytical Techniques & Advantages & Disadvantages \\
\hline $\begin{array}{l}\text { Thin Layer } \\
\text { Chromatography (TLC) }\end{array}$ & $\begin{array}{l}\text { Simple, inexpensive \& rapid } \\
\text { Can be used for screening } \\
\text { Simultaneous analysis of multiple mycotoxins } \\
\text { Suitable for ochratoxin and aflatoxin }\end{array}$ & $\begin{array}{l}\text { Poor sensitivity (for some mycotoxins) } \\
\text { Poor precision } \\
\text { Adequate separation may require } 2 \\
\text { dimensions analysis } \\
\text { Quantitative when used with a densimeter }\end{array}$ \\
\hline Gas Chromatography (GC) & $\begin{array}{l}\text { Simultaneous analysis of multiple mycotoxins } \\
\text { Good sensitivity } \\
\text { May be automated (auto sampler) } \\
\text { Provide confirmation (MS detection) }\end{array}$ & $\begin{array}{l}\text { Expensive instrument } \\
\text { Need expertise } \\
\text { Derivatization required } \\
\text { Matrix interface problem } \\
\text { Non-linear calibration curve } \\
\text { Drifting response } \\
\text { Carry-over effect from previous sample } \\
\text { Variation in reproducibility and repeatability }\end{array}$ \\
\hline $\begin{array}{l}\text { High Performance Liquid } \\
\text { Chromatography (HPLC) }\end{array}$ & $\begin{array}{l}\text { Good sensitivity } \\
\text { Good selectivity } \\
\text { May be automated } \\
\text { Short analysis time } \\
\text { Official method available }\end{array}$ & $\begin{array}{l}\text { Expensive instrument } \\
\text { Need expertise } \\
\text { Derivatization may required }\end{array}$ \\
\hline LC/Mass Spectroscopy & $\begin{array}{l}\text { Good sensitivity } \mathrm{LC} / \mathrm{MS} / \mathrm{GC} \\
\text { Simultaneous analysis of multiple mycotoxins } \\
\text { Provide confirmation } \\
\text { No derivation require }\end{array}$ & $\begin{array}{l}\text { Expensive instrument } \\
\text { Need expertise } \\
\text { Matrix assisted calibration curve } \\
\text { (for quantitative analysis) }\end{array}$ \\
\hline $\begin{array}{l}\text { Real Rime polymerase } \\
\text { chain reaction (PCR) }\end{array}$ & $\begin{array}{l}\text { Good Sensitivity } \\
\text { Accurate } \\
\text { Suitable for high throughput analysis }\end{array}$ & $\begin{array}{l}\text { Time taking } \\
\text { Error during polymerase }\end{array}$ \\
\hline $\begin{array}{l}\text { Enzyme Linked } \\
\text { Immunosorbant Assays } \\
\text { (ELISA) }\end{array}$ & $\begin{array}{l}\text { Simple sample preparation } \\
\text { Inexpensive equipment } \\
\text { Simultaneous analysis of multiple mycotoxins } \\
\text { Suitable for screening } \\
\text { Limited used of organic solvents } \\
\text { Visual assessment }\end{array}$ & $\begin{array}{l}\text { Cross reactivity with related myco toxins } \\
\text { Matrix interface problem } \\
\text { Possible false +ve/-ve results } \\
\text { Critical quantization near regular limit } \\
\text { Semi-quantitative (visual assessment) }\end{array}$ \\
\hline $\begin{array}{l}\text { Rapid tests } \\
\text { Membrane based cards } \\
\text { Antibody based tubes } \\
\text { Immuno cup test }\end{array}$ & $\begin{array}{l}\text { Simple and fast }(5-10 \mathrm{~min}) \\
\text { No expensive equipment required } \\
\text { Limited use of organic solvents } \\
\text { Suitable for screening } \\
\text { Can be used in-situ }\end{array}$ & $\begin{array}{l}\text { Quantitative or semi quantitative } \\
\text { (cut off level) } \\
\text { Possible false +ve/-ve results } \\
\text { Cross reactivity with related mycotoxins } \\
\text { Matrix interface problem } \\
\text { Lack of sensitivity near regular limit }\end{array}$ \\
\hline Electrochemical Biosensor & $\begin{array}{l}\text { Rapid and cost-effective } \\
\text { Good selectivity and sensitivity } \\
\text { Portable, no expertise required } \\
\text { Used for multiple mycotoxins detection } \\
\text { Suitable for screening } \\
\text { Commercial issues are open }\end{array}$ & $\begin{array}{l}\text { Selection of immobilizing matrix and } \\
\text { techniques is crucial to optimize best } \\
\text { electrical parameters to obtain enhanced } \\
\text { sensing performance }\end{array}$ \\
\hline
\end{tabular}

Among mycotoxins, OTA, OT-B \& C, aflatoxin B1, B2, B3 \& M1, citeroviridin, patrulin, citrinin and zearalenon are widely studied due to their known adverse effect on human/animal health though food and beverage consumption. Among these OTA has gained much attention recently.

OTA, the toxic metabolite, produced by several fungal species such as genera Aspergillus and Penicillium, is present in food and food products due to the thermostability of its derivatives [6]. OTA has been widely detected in cereal-derived products, dried fruits, spices, beer, and wine [7]. Strains of OTA from Aspergillus carbonarius and Aspergillus niger, that contaminate grapes, has been found in wines [8]. Additionally, OTA in large amounts has been found in animal feed $[9,10]$. OTA in cereals is mainly produced by $P$. verrucosum, while OTA in grapes, coffee and cocoa is formed by $A$. Carbonarius. As concerned with agricultural food safety, OTA has been found to be responsible for the contamination of several agricultural products.

The critical factors that affect fungal growth during farming, harvesting, and storage of commodities susceptible to OTA are temperature, moisture content, and exposure time. Additional factors that support fungal growth 
are the presence of spores, the physical location (the internal part of a vegetable is more vulnerable to fungal invasion than the external area), insects (due to their metabolism, they increase the moisture and temperature of the plant and break its protective shield), storm and rain damage, moisture stress, the availability of mineral nutrient, $\mathrm{pH}$ (in general, mold tolerates acid media and is able to acidify the media themselves), oxygen and carbon dioxide levels, chemical and physical treatments, and, for some commodities, the product drying and re-wetting speed [11].

OTA is the most detected mycotoxin in human blood globally due to its binding with plasma protein, long elimination half-life ( $\sim 35$ days in serum), its enterohepatic circulation and its reabsorption from urine [12]. Human exposure to OTA has been clearly demonstrated through its detection in human blood, urine and food [13]. In animal species, OTA has shown many adverse effects such as teratogenicity [14], immunotoxicity [15], genotoxicity [16] and mutagenicity [17]. The most important toxic effect of this mycotoxin is its nephrotoxicity [2] leading to conditions such as "Balkan Endemic Nephropathy" [18]. In 1993, the International Agency for Research on Cancer (IARC) classified OTA in group 2B, a possible human carcinogen due to induction of oxidative DNA [18]. The proposed hypothesis of OTA causing cancer is shown in Figure 3.

Keeping these adverse effects in mind various health organizations have set OTA consumption limits. The World Health Organization has established the provisional tolerable weekly intake of OTA as $100 \mathrm{ng} \cdot \mathrm{kg}^{-1}$ of body weight (equivalent to $14 \mathrm{ng} \cdot \mathrm{kg}^{-1}$ body weight/day) $[6,7]$. The European commission has set the following limits of OTA contamination: $10.0 \mu \mathrm{g} \cdot \mathrm{kg}^{-1}$ for dried fruits and soluble coffee, $5.0 \mu \mathrm{g} \cdot \mathrm{kg}^{-1}$ for raw cereal grains and roasted coffee, $3.0 \mu \mathrm{g} \cdot \mathrm{kg}^{-1}$ for cereals intended for human consumption, $2.0 \mu \mathrm{g} \cdot \mathrm{kg}^{-1}$ for wine and

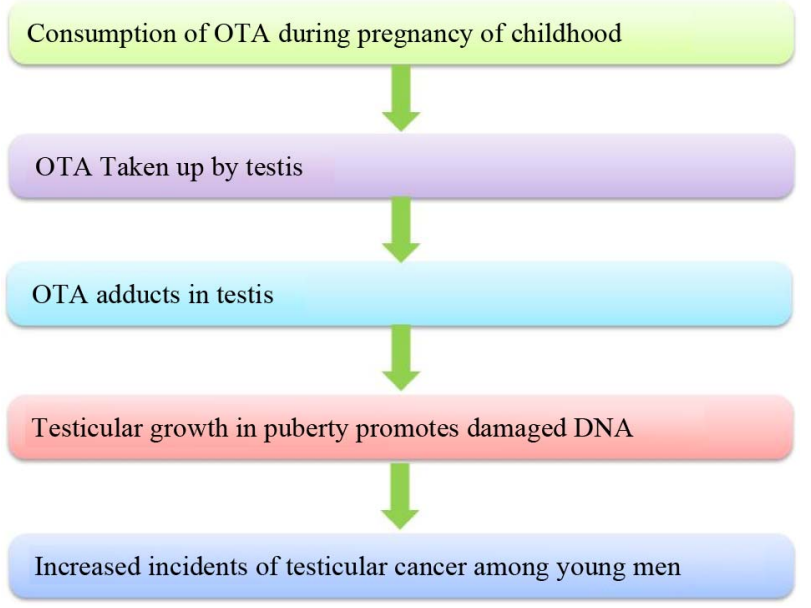

Figure 3. Hypothesis for OTA to cause testicular cancer. grape juice and $0.5 \mu \mathrm{g} \cdot \mathrm{kg}^{-1}$ for baby foods and cerealbased foods intended for young children (European Commission) [6,7]. Thus precise, rapid and selective detection of OTA is warranted for human health care and for diagnostics. The various methods used for the estimation of OTA are discussed in next section.

\section{Current Approaches for Detection of OTA}

OTA and other food borne contaminants come in a variety of sizes ranging from simple chemical compounds to entire bacterial cells. Due to public health concerns, there is an overwhelming need in the food industry for sensitive, specific, and rapid methods to monitor the presence of OTA $[19,20]$. This can be achieved by setting up hazard critical control point concepts, which "filter" out all those lots displaying certain levels of the toxin. According to the hazard critical control point philosophy, analytical concepts demand methods that fulfill the following needs a) analytical target must be a direct marker for the hazard that needs to be controlled, b) marker must be indicative for the future toxigenic potential of a sample as well as for its mycological history, c) sensitivity of the analysis must be high enough to detect hazardous samples, d) results must enable decisions to be taken on whether or not a given lot should pass or fail the control point, e) screening of vast numbers of samples must be possible, e.g. the procedure must have an automatable format for high-throughput applications, f) results must be available in a short time, g) tests must be usable by relatively unskilled personnel and h) Tests must be inexpensive and easy to use, as must the equipment used to perform them.

In this context, chromatographic analytical tools such as thin layer chromatography (TLC) and high performance liquid chromatography (HPLC) have been used for detection OTA using low volume samples as well as quicker sample clean-up. Pittet et al. reported a screening method for the detection of OTA (range 0.2 to 136.7 $\mu \mathrm{g} \cdot \mathrm{kg}^{-1}$ ) in green coffee at a control level of $10 \mu \mathrm{g} \cdot \mathrm{kg}^{-1}$ using TLC [21]. Varelis et al. described the use of reverse-phase HPLC-fluorescence detection (FD) with post column ammonisation to improve the detection limit for OTA in wine and beer with the high precision and concentration range of $0.016-1.284 \mathrm{mg} \cdot \cdot^{-1}$ [22]. Reinsch et al. combined the anion exchange/reversed phase clean-up and liquid chromatography (LC) with tandem mass spectrometry to detect OTA in beer [23]. The method exhibits a detection range from 1.17 to $5.56 \mu \mathrm{g} \cdot \mathrm{kg}^{-1}$, and a detection limit of $0.4 \mu \mathrm{g} \cdot \mathrm{kg}^{-1}$ and limit of quantification of 0.8 $\mu \mathrm{g} / \mathrm{kg}$. Juan et al. reported HPLC-FD to detect OTA in maize bread samples via extraction with PBS, methanol (50:50) and clean-up with immuno-affinity column [24]. The limit of quantification was obtained as $0.033 \mathrm{ng} / \mathrm{g}$ 
and recoveries ranged from $87 \%$ to $102 \%$ for concentration range 2.0 and $0.5 \mathrm{ng} \cdot \mathrm{g}^{-1}$, respectively. Caputo et al. fabricated a hydrogenated amorphous silicon (a-Si:H) sensor for detection of OTA [25]. Selma et al. developed a new real-time (RTi) polymerase chain reaction (PCR) based procedure for the rapid and specific detection and quantification of OTA. RTi-PCR assay is a promising tool for the prediction of potential ochratoxicogenic risk, even in the case of low-level infections, and is suitable for rapid, automated, and high throughput analysis [26]. Flajs et al. reported enzyme linked immunosorbant assays (ELISA) and HPLC for OTA analysis on wine samples collected in Croatia [19]. The results of ELISA and HPLC analysis of OTA in naturally contaminated red wines correlated well at higher OTA concentrations. Ghali et al. studied the detection of 180 samples of OTA contaminated food using HPLC [27]. The experimental analysis indicated that $45 \%$ of monitored samples were contaminated with levels ranging from $0.11-33.9 \mathrm{ng} \cdot \mathrm{g}^{-1}$. Lai et al. prepared a rapid, inexpensive and user-friendly lateral flow strip assay ideally suited for onsite testing of OTA [28]. Mimotope peptide capable of mimicking OTA by panning from a M13 phage-displayed random seven-peptide was used instead of OTA-protein conjugate. $10 \mathrm{ppb}$ of OTA was detected in 10 min using this new strip. These techniques provide precise results however they are very expensive, require expertise and are susceptible to false positive results. Conversely, ELISA is a rapid, simple, specific, and sensitive technique but may occasionally result in a systematic overestimation when compared to the chromatographic methods. Recently, immunosensors have attracted considerable attention for OTA and other mycotoxin detection because they lead to rapid analysis, selectivity, sensitivity, costeffectiveness and are user friendly [20,29-31].

\section{Recent Advances in OTA Detection Using Immunosensors}

Estimation of OTA using immunosensors is getting main stream [32]. Tsai et al. fabricated a piezoelectric immunosensor based on self-assembled monolayer of 16-mercaptohexadecanoic acid (16-MHDA) to detect OTA using quartz crystal microbalance (QCM) [33]. The fabricated immunosensor exhibited detection range from 50 to $1000 \mathrm{ng} \cdot \mathrm{mL}^{-1}$, detection limit $\sim 16.1 \mathrm{ng} / \mathrm{mL}$ with negligible effect of interference. Ngundi et al. reported the development of a rapid and highly sensitive competetive immunoassay for the detection and quantification of OTA [34]. OTA was quantified by measuring the formation of the fluorescent immuno-complex on the waveguide surface. The limit of detection for OTA in several cereals has been reported in a range of $3.8-100$ $\mathrm{ng} \cdot \mathrm{g}^{-1}$, while in coffee and wine, detection limits were 7 and $38 \mathrm{ng} / \mathrm{g}$ respectively. Adanyi et al. used the optical waveguide light mode spectroscopy (OWLS) techniques for the detection of aflatoxin and OTA in both competetive and direct immunoassays wherein a microchip utilized a flow-injection analyser (FIA) system [34].

Prieto-Simon et al. reported OTA detection [35] through immobilization of polyclonal (PAb) and monoclonal $(\mathrm{MAb})$ antibodies. The sensor demonstrated values at least one-order of magnitude lower $\left(\mathrm{IC}_{50}\right)$ when working with MAb. Considering $80 \%$ of antibody binding, both HRP and alkaline phosphatise (ALP) labelled immunosensor showed detection limit of 0.7 and $0.3 \mathrm{ng} / \mathrm{mL}$, respectively.

Ansari et al. have reported a zinc oxide $(\mathrm{ZnO})$ based impedimetric immunosensor for OTA detection that exhibited a linearity of $0.006-0.01 \mathrm{nM} \cdot\left(\mathrm{dm}^{3}\right)^{-1}$, detection limit of $0.006 \mathrm{nM} \cdot\left(\mathrm{dm}^{3}\right)^{-1}$, response time of $25 \mathrm{~s}$ and sensitivity of $189 \Omega \cdot \mathrm{nM}^{-1} \cdot\left(\mathrm{dm}^{3}\right)^{-1} \cdot \mathrm{cm}^{-2}$ with a regression coefficient of 0.997 [36]. Kaushik et al. have utilized sol-gel derived cerium oxide $\left(\mathrm{CeO}_{2}\right)$ nanostructured platform for the fabrication of electrochemical immunosensor to detect OTA [37]. This $\mathrm{CeO}_{2}$ based immunoelectrode exhibited a linear range $\left(0.5-6 \mathrm{ng} \cdot \mathrm{dL}^{-1}\right)$, low detection limit $\left(0.25 \mathrm{ng} \cdot \mathrm{dL}^{-1}\right)$, fast response time of $(30 \mathrm{~s})$ and high sensitivity $\left(1.27 \mu \mathrm{A} \cdot \mathrm{ng}^{-1} \cdot \mathrm{dL}^{-1} \cdot \mathrm{cm}^{-2}\right.$. The obtained high value of the association constant $(\mathrm{Ka}, 0.9 \times$ $10^{11} 1 \cdot \mathrm{mol}^{-1}$ ) reveals the high affinity of immobilized antibody with OTA. Radi et al. prepared a novel, label-free, Electrochemical Impedance Spectroscopy (EIS) immunosensor to detect OTA [38] that exhibited linearity in the range $1-20 \mathrm{ng} \cdot \mathrm{mL}^{-1}$, with a detection limit of 0.5 $\mathrm{ng} \cdot \mathrm{mL}$. Radi et al. also proposed a protocol to fabricate competitive immunosensor for OTA detection via immobilizing horseradish peroxidase (HRP) labelled OTA antibodies onto 4-nitropheny modified screen-printed gold $(\mathrm{Au})$ electrode. The electrochemical response was observed using 3,3',5,5'-tetramethylbenzidine as substrate. This immunosensor exhibits detection limit of 12 $\mathrm{ng} \cdot \mathrm{mL}^{-1}$ and a dynamic range up to $60 \mathrm{ng} \cdot \mathrm{mL}^{-1}$ of OTA [39] Aptamer-DNA enzyme hairpin as a biorecognition element has been used to detect OTA, wherein self-assembly of the active HRP-mimicking DNA enzyme occurs, and exhibits detection up to $10 \mathrm{nM}$ and detection limit of $2.5 \mathrm{nM}$ [40]. DNA aptamers based electrochemical impedance biosensor was utilized for the detection of OTA which exhibited detection range of $0.1-100 \mathrm{nM}$ with the detection limit of $0.44 \mathrm{nM}[41,42]$.

OTA-bovine serum albumin (OTA-BSA) has been conjugated onto gold-coated quartz crystals (AT-cut/5 $\mathrm{MHz}$ ) to fabricate flow-injection based piezoelectric immunosensor to detect OTA. 3D procedures for the direct adsorption and covalent attachment to two alkane thiol self-assembled monolayers were characterized using QCM in real time. The immunosensor was efficient 
to detect OTA in concentration range from 10 to 128 $\mathrm{ng} \cdot \mathrm{mL}^{-1}$, and detection limit as $8 \mathrm{ng} \cdot \mathrm{mL}^{-1}$. Moreover, the immunocomplex formed due to antigen-antibody binding can be released pepsin of $2 \mathrm{mg} \cdot \mathrm{mL}^{-1}(\mathrm{pH}=2.1)$ solution to regenerate the bio recognition surface [43]. EIS coupled with QCM has been utilized for the detection of OTA via immobilizing antibodies onto mercaptoundecanol/mercaptoundecanoic acid which was mixed with self-assembled monolayer modified gold electrode. It was observed that the increase of the relative change of charge transfer resistance was proportional to OTA concentration and found linear between 100 and 1000 $\mathrm{pg} \cdot \mathrm{mL}^{-1}[44]$.

Liu et al. fabricated an electrochemical immunosensor based on self-assembled monolayer of 1,6-hexanedithiol fabricated onto Au colloid layer via immobilizing OTAovalbumin conjugate [45]. The fabricated immunosensor exhibited the detection ranging from $10 \mathrm{pg} \cdot \mathrm{mL}^{-1}$ to 100 $\mathrm{ng} \cdot \mathrm{mL}^{-1}$ and detection limit of $8.2 \mathrm{pg} \cdot \mathrm{mL}^{-1}$. Prabhakar $e t$ al. utilized a Langmuir-Blodgett film of polyaniline (PANI)-stearic acid (SA) to fabricate an aptamer based impedimetric immunosensor to detect OTA [46]. The electrochemical response studies suggested that AptDNA/PANI-SA/ITO exhibits linear range of $0.1 \mathrm{ng} \cdot \mathrm{mL}^{-1}$ to $10 \mathrm{ng} \cdot \mathrm{mL}^{-1}$ and $1 \mu \mathrm{g} \cdot \mathrm{mL}^{-1}-25 \mu \mathrm{g} \cdot \mathrm{mL}^{-1}$ with detection limit of $0.1 \mathrm{ng} \cdot \mathrm{mL}^{-1}$ in $15 \mathrm{~min}$. Sensing electrode was found to be 13 times reusable with affinity constant, estimated using Langmuir adsorption isotherm, as $1.21 \times$ $10^{7} \mathrm{M}^{-1}$. Zamfir et al. proposed magnetic nanoparticles based label-free immunosensor for the detection of OTA using EIS/surface plasmon resonance (SPR) techniques. The impedametric parameters i.e., $\mathrm{R}_{\mathrm{ct}}$ variation was found to be antibody-OTA interaction dependent which exhibited linear range of $0.01-5 \mathrm{ng} \cdot \mathrm{mL}^{-1}$ with a detection limit as $0.01 \mathrm{ng} \cdot \mathrm{mL}^{-1}$. A larger response range from 1 to $50 \mathrm{ng} \cdot \mathrm{mL}^{-1}$ with a detection limit of $0.94 \mathrm{ng} \cdot \mathrm{mL}^{-1}$ was observed in case of OTA detection using SPR [47]. Solanki et al., have immobilized anti-OTA antibody onto self-assembled monolayer of 11-Amino-1-undecanethanol for the selective detection of OTA in coffee sample using EIS technique [48]. The results of the studies revealed linearity from $0.5 \mathrm{ng} \cdot \mathrm{dL}^{-1}-6.0 \mathrm{ng} \cdot \mathrm{dL}^{-1}$, detection limit of $0.08 \mathrm{ng} \cdot \mathrm{dL}^{-1}$ and sensitivity of $36.83 \Omega \cdot \mathrm{ng}^{-1}$. $\mathrm{dL}^{-1} \cdot \mathrm{cm}^{-2}$ with a regression coefficient of 0.999 . Authors have validated fabricated immunosensor to estimate OTA in coffee samples.

Recently, nanostructured platform such as metals, metal oxides, quantum dots, self-assembled monolayers, conducting/biopolymers and hybrid nanocomposites have been employed in immunosensor fabrication [49]. Inorganic nanostructured materials such as metals or metal oxides are crystalline materials with precise chemical composition, surface terminations, and are dislocation-defect free [50,51]. Surface effects appear be- cause of the magnification in the specific surface of nanostructures, which leads to an enhancement of the properties such as catalytic activity or surface adsorption. This enhancement allow these materials to be used in many applications such as catalysis, fuel cell, heavy metal detection, photonic band-gap materials, single electron transistors, non-linear optical devices, biotechnology etc. [52,53].

The unique electrical and optical properties of organic nanostructures such as conducting polymers [PANI, etc.] [54-57], biopolymers [chitosan (CH), etc.] [58-63], and self-assembled monolayers [64] helps to exhibit the ease in synthesis with desired functionality and therefore makes them promising candidates for a wide range of electronic, optoelectronic and molecular electronic applications. The changes in electrical and optical properties of conducting polymers combined with interaction of oxidizing or reducing agents make them suitable materials for desired applications. The conducting polymers which can make a transition from an initial insulating state to an electrically conducting state after the chemical treatment with redox active agents have been widely exploited for optical and bio/gas sensors $[55,56]$. However, the problem of stability and its interaction with moieties present in environment limits the application of most of the organic materials. Consequently, biopolymers such as $\mathrm{CH}$, due to their excellent optical, mechanical, and electrical properties, have been used in industrial and medical applications such as bioplastics, medical devices, tissue engineering, and drug delivery [58]. Efforts are continuing towards the engineering of nanomaterials to obtain improved optical and electrical properties for desired applications. In this context, the possibility of combining properties of organic and inorganic components at the same platform on the basis of organic-inorganic hybrid materials at nanoscale is a new approach to design new functional materials with desired properties.

Organic-inorganic hybrid nanocomposites, such as conducting polymer-metal/metal oxides and biopolymermetal/metal oxides, are the new class of materials wherein nanocomposites exhibit the properties of organic as well as inorganic counterparts, along with some new properties that are absent in counterpart molecules. These unique properties of organic-inorganic hybrid nanocomposite can be exploited for various applications such as mechanically reinforced lightweight components, non-linear optics, battery cathodes, nanowires, optics, electronics, ionics, mechanics, membranes, protective coatings, catalysis, sensors, biology etc. [65-67]. Hybrid nanocomposites systems can be used for biomimetic artificial systems (i.e. membranes, vesicles, liposomes, enzymes, etc.) that exhibit behaviour similar to those of living bodies and are also complex architectural assemblies [68-70]. Because of their exceptional biocompatibility, optical, 
and electrical properties due to electron and phonon confinement organic-inorganic hybrid nanocomposites are receiving a great deal of attention as alternative matrices for biomolecule immobilization aiming to improve stability and sensitivity of desired biosensor [71,72]. These systems can be used to immobilize desired biomolecules such as enzymes, antibodies or micro-organisms with high activity and natural state to perform specific reactions that would not be possible with the usual chemical routes. The organization and properties that can be obtained for organic-inorganic hybrid nanocomposite materials certainly depend on the chemical natures of their parent components, but they also rely on the synergy between their counterparts. These hybrid nanocomposites can be prepared using sol-gel technique, assembly of nanobuilding blocks, self-assembly of nanomaterials, integrative, and electrochemical methods [66,73-79]. Recently, among hybrid nanocomposites, nanostructured $\mathrm{CH}$ and metal/metal oxide nanoparticle based hybrid nanocomposite systems are being studied for fabrication of biosensor fabrication [58,61-63,80] and have been utilised for OTA detection (discussed in next section).

\section{CH Nanocomposites Based Immunosensor for OTA Detection}

In recent years, $\mathrm{CH}$ has potentially been used as an immobilization matrix for cell carriers, living organisms, or enzymes/DNA/antibody [70,81-84]. The unique structural feature of $\mathrm{CH}$ is the presence of amine groups at the
C-2 position of glucosamine residue resulting in important functional properties that can be used for biosensor applications. $\mathrm{CH}$ has been reported as a rather important emerging immobilization matrix in various pharmaceutical, environmental and biotechnological applications due to its excellent film-forming ability, good adhesion, biocompatibility, high mechanical strength, and susceptibility to chemical modifications due to the presence of reactive hydroxyl and amino functional groups. Moreover, widely present amino and hydroxyl groups present in $\mathrm{CH}$ molecules facilitate immobilization of biomolecules via covalent binding, electrostatic interactions, etc. Therefore numerous processes using $\mathrm{CH}$ and enzyme immobilization are well-established in various fields [85-88] for example in contact lenses [89], as drug nano-carriers [90], as a matrix for cell [91] and as desired biomolecules immobilization [92] and artificial skin [93]. The derivatives of $\mathrm{CH}$ are being potentially used for biomedical applications [94].

Recently, nanocomposite of CH-metal/metal oxide has emerged as an appropriate, suitable, and micro-friendly immobilizing matrix and has been employed to fabricate electrochemical immunosensor for OTA detection with improved sensing characteristics. The proposed schematic for the fabrication of $\mathrm{CH}$-metal/metal oxide based nanocomposite platform to fabricate electrochemical immunosensors for the rapid, selective, specific, and sensitive detection of OTA is shown in Figure 4.

Electrochemical impedimetric immunosensors have

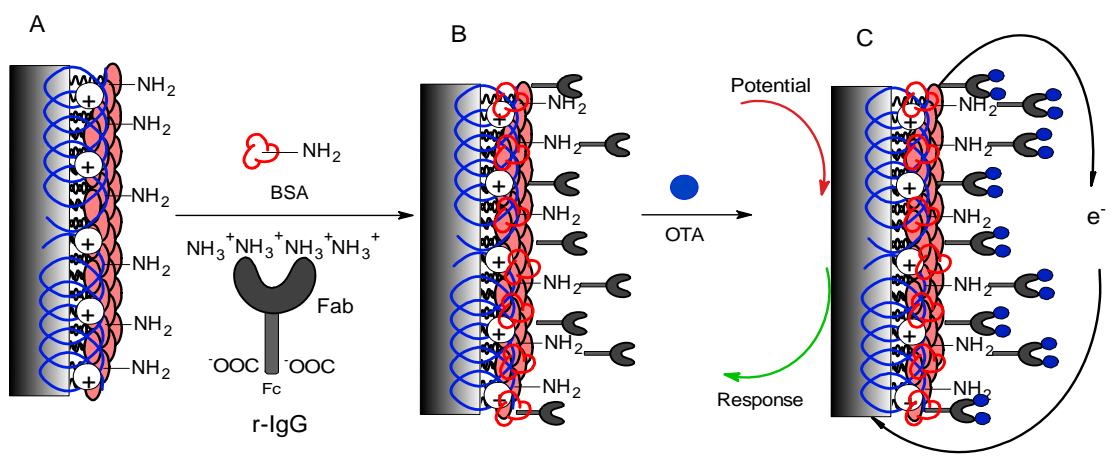

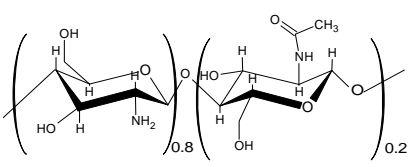

Chitosan $(\mathrm{CH})$

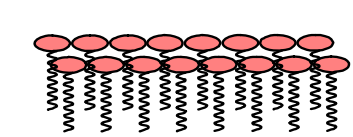

Metal-Metal oxides Nanoparticles

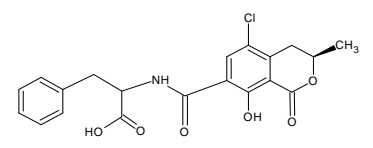

Ochratoxin-A (OTA)

$$
\begin{aligned}
& \mathrm{A}=\mathrm{CH}-\mathrm{Nano} \text { Metal-Metal oxides/ITO nanobiocomposite } \\
& \mathrm{B}=\mathrm{BSA} / \mathrm{IgGs} / \mathrm{CH}-\mathrm{Nano} \text { Metal-Metal oxides/ITO immunoelectrode } \\
& \mathrm{C}=\text { OTA-Immunoelectode interaction }
\end{aligned}
$$

Figure 4. The proposed schematic for the stepwise fabrication of CH-Metal oxide nanocomposite based immunosensor for OTA detection. 
been proposed by Khan and Dhayal using nanocomposite films based on $\mathrm{CH}$ and $\mathrm{TiO}_{2}$ nanoparticles to immobilize Abs for OTA detection. The $\mathrm{CH}-\mathrm{TiO}_{2}$ nanocomposite based immunosensor exhibited linearity in $1-10 \mathrm{ng} \cdot \mathrm{dL}^{-1}$ range with the detection limit of $1 \mathrm{ng} \cdot \mathrm{dL}^{-1}$ [95]. Khan et al. also prepared an impedimetric immunosensor for OTA detection using hybrid film of PANI and $\mathrm{CH}$ to immobilize r-IgGs. OTA interaction with IgGs increases $\mathrm{R}_{\mathrm{CT}}$ values and shows linear response up to $1-10$ $\mathrm{ng} \cdot \mathrm{mL}^{-1}$ with absolute sensitivity of $53 \pm 8 \mathrm{~mL} \cdot \mathrm{ng}^{-1}$ [96].

Studies by Kaushik et al. revealed that surface charged $\mathrm{CH}$ film can be used to detect OTA via immobilization of r-IgGs. Further, the presence of $\mathrm{NH}_{2} / \mathrm{OH}$ groups in $\mathrm{CH}$ provides a favorable microenvironment for immobilization of IgGs leading to enhanced electron transfer to the electrode. They showed that the $\mathrm{CH}$ based immunosensor shows improved characteristics such as linearity (1 - 6 $\left.\mathrm{ng} \cdot \mathrm{dL}^{-1}\right)$, low detection limit $\left(1 \mathrm{ng} \cdot \mathrm{dL}^{-1}\right)$, fast response time $(25 \mathrm{~s})$, high sensitivity $\left(4.8 \times 10^{-8} \mathrm{~A} \cdot \mathrm{dL}^{-1}\right)$, reproducibility ( $>10$ times), and long term stability (30 days) in comparison to that of the $\mathrm{CH} / \mathrm{ITO}$ based immunosensor [97]. In another study, nanoCeO $\mathrm{C}_{2}$ was incorporated into $\mathrm{CH}$ to fabricate $\mathrm{CH}-\mathrm{NanoCeO}_{2}$ nanobiocomposite film onto ITO substrate for the co-immobilization of r-IgGs and BSA to detect OTA [61]. The results of electrochemical studies revealed that the presence of Nano$\mathrm{CeO}_{2}$ in $\mathrm{CH}-\mathrm{NanoCeO}_{2} / \mathrm{ITO}$ nanobiocomposite increases the effective surface area of $\mathrm{CH}$ resulting in improved loading of $\mathrm{r}-\mathrm{IgGs}$. Electrochemical response of $\mathrm{BSA} /$ r-IgGs/CH-NanoCeO $\mathrm{Ce}_{2} / \mathrm{ITO}$ immunoelectrode was obtained as a function of OTA concentration exhibits linearity in the range of $0.25-6.0 \mathrm{ng} \cdot \mathrm{dL}^{-1}$, detection limit of $0.25 \mathrm{ng} \cdot \mathrm{dL}^{-1}$, response time of $25 \mathrm{~s}$, sensitivity of 18 $\mu \mathrm{A} \cdot \mathrm{ng}^{-1} \cdot \mathrm{dL}^{-1} \cdot \mathrm{cm}^{-2}$ with 0.997 regression coefficient and standard deviation of $0.28 \times 10^{-5} \mu \mathrm{A} \cdot \mathrm{ng}^{-1} \cdot \mathrm{dL}^{-1}$. BSA/ $\mathrm{r}$-IgGs/CH-NanoCeO $\mathrm{Ce}_{2} / \mathrm{ITO}$ immunosensor was found to exhibit improved sensing characteristics than that of the sol-gel derived $\mathrm{NanoCeO}_{2}$ and $\mathrm{CH}$ based immunoelectrode for OTA detection [61].

Recently, Kaushik et al. fabricated $\mathrm{NanoSiO}_{2}$ and $\mathrm{CH}$ based nanobiocomposite film onto an ITO substrate to co-immobilize r-IgGs and BSA for OTA detection [63]. The observed three-dimensional (3D) arrangement of $\mathrm{NanoSiO}_{2}$ in $\mathrm{CH}$ matrix via hydrogen bonding, available $\mathrm{NH}_{2} / \mathrm{OH}$ groups, and excellent film forming abilities of $\mathrm{CH}$ resulted in an increased effective surface area of $\mathrm{CH}-\mathrm{NanoSiO}_{2}$ nanobiocomposite for r-IgGs immobilization resulted in enhanced electron transport between r-IgGs and electrode. It has been shown that BSA/ r-IgGs/CH-NanoSiO $/$ /ITO immunoelectrode can be used for OTA detection with improved sensing characteristics. Electrochemical studies suggest that the presence of $\mathrm{NanoSiO}_{2}$ leads to enhanced electrochemical behavior of $\mathrm{CH}$ resulting in increased electron transport between the medium and the electrode. BSA/r-IgGs/CH-NanoSiO $2 /$ ITO immunoelectrode exhibited improved sensing characteristics such as linearity $\left(0.5-6 \mathrm{ng} \cdot \mathrm{dL}^{-1}\right)$, detection limit $\left(0.3 \mathrm{ng} \cdot \mathrm{dL}^{-1}\right)$, response time $(25 \mathrm{~s})$ and sensitivity $\left(18 \mu \mathrm{A} \mathrm{ng} \cdot \mathrm{dL}^{-1} \cdot \mathrm{cm}^{-2}\right)$ with a correlation coefficient of 0.98. CH-NanoSiO ${ }_{2}$ nanobiocomposite based immunosensor platform can be used for detection of other mycotoxins. Moreover, authors have studied the co-immobilization of r-IgGs and BSA onto nanobiocomposite films of $\mathrm{CH}$ and superparamagnetic $\mathrm{Fe}_{3} \mathrm{O}_{4}$ nanoparticles for detection of OTA [95]. Herein, surface charged $\mathrm{Fe}_{3} \mathrm{O}_{4}$ nanoparticles were self-assembled in $\mathrm{CH}$ bio-polymeric matrix to prepare nanobiocomposites. It was observed that in the nanobiocomposites, $\mathrm{NanoFe}_{3} \mathrm{O}_{4}$ results in increased electro-active surface area wherein, affinity of surface charged $\mathrm{NanoFe}_{3} \mathrm{O}_{4}$ supported the immobilization of r-IgGs and led to enhanced electron transfer. Differential pulse voltammetry (DPV) studies indicate that $\mathrm{Fe}_{3} \mathrm{O}_{4}$ nanoparticles provide increased electro active surface area for loading of $\mathrm{r}$-IgGs and improved electron transport between IgGs and electrode. BSA/r-IgGs/CH-Nan$\mathrm{oFe}_{3} \mathrm{O}_{4} / \mathrm{ITO}$ immunoelectrode exhibited improved sensing characteristics such as low detection limit $(0.5 \mathrm{ng}$ $\left.\mathrm{dl}^{-1}\right)$, fast response time (18 s) and high sensitivity (36 $\mu \mathrm{A} \cdot \mathrm{ng}^{-1} \cdot \mathrm{dL}^{-1} \cdot \mathrm{cm}^{-2}$ ) with respect to other $\mathrm{CH}$ based nanocomposite immunoelectrode. Kaushik et al., incorporated MWCNT/CWCNT into polymer backbone of $\mathrm{CH}$ to prepare hybrid nanocomposite film for the immobilization of r-IgG to detection OTA [62]. The results of electrochemical studies revealed that $\mathrm{CH}-\mathrm{SWCNT}$ based biosensor exhibited better sensing characteristics than that of CH-MWNCTS based immunoelectrode due to more electro-active surface area and enhanced electron transfer kinetics. CH-SWCNT/ITO immunoelectrode exhibits improved linearity as $0.25-6 \mathrm{ng} \cdot \mathrm{dL}^{-1}$, detection limit as $0.25 \mathrm{ng} \cdot \mathrm{dL}^{-1}$, response time as $25 \mathrm{~s}$, and sensitivity as $21 \mu \mathrm{A} \cdot \mathrm{ng} \cdot \mathrm{dL}^{-1} \cdot \mathrm{cm}^{-2}$ with the regression coefficient as 0.998 . The work presented by Kaushik et al., was based on polyclonal antibody based OTA detection and may exhibit the problem of specificity. Besides this, the utilized $\mathrm{CH}$ based nanocomposites are found to be highly electroactive and are suitable for fabrication of efficient immunosensors for OTA detection. To overcome the problem of selectivity, polyaclononal antibody can be replaced with monoclonal antibody or aptamers during immunosensor fabrication using $\mathrm{CH}$-metal/metal oxide hybrid nanocomposite for the selective detection of OTA.

\section{Conclusion}

Among the various OTA detection techniques, electrochemical biosensors have proven potential for the detection of OTA. In the future, new types of organic-inorganic hybrid nanocomposites having capabilities to pro- 
vide better matrices for immobilization of desired biomolecules in the fabrication of biosensors will provide better optical, electrical and molecular responses for better selectivity and sensitivity. As recent developments, polyclonal antibody has been replaced by monoclonal antibody and aptamers to detect OTA. Efforts are being made to optimize OTA immunosensors for real sample analysis. Studies suggest that there is market for the commercial development of these immunosensors for practical, on-site, selective and specific detection of OTA.

\section{Acknowledgements}

This work is partially supported through NSF, ERC1160483 .

\section{REFERENCES}

[1] W. L. Bryden, "Mycotoxin Contamination of the Feed Supply Chain: Implications for Animal Productivity and Feed Security," Animal Feed Science and Technology, Vol. 173, No. 1, 2012, pp. 134-158. doi:10.1016/j.anifeedsci.2011.12.014

[2] S. Bräse, A. Encinas, J. Keck and C. F. Nising, "Chemistry and Biology of Mycotoxins and Related Fungal Metabolites," Chemical Reviews, Vol. 109, No. 9, 2009, pp. 3903-3990.

[3] R. Krska and A. Molinelli, "Mycotoxin Analysis: Stateof-the-Art and Future Trends," Analytical and Bioanalytical Chemistry, Vol. 387, No. 1, 2007, pp. 145-148. doi:10.1007/s00216-006-0797-3

[4] B. Prieto-Simón, T. Noguer and M. Campàs, "Emerging Biotools for Assessment of Mycotoxins in the Past Decade," TrAC Trends in Analytical Chemistry, Vol. 26, No. 7, 2007, pp. 689-702. doi:10.1016/j.trac.2007.05.012

[5] L. Yotova, I. Grabchev, R. Betcheva and D. Marinkova, "Smart Biosensors for Determination of Mycotoxines," In: M. V. Magni, Ed., Detection of Bacteria, Viruses, Parasites and Fungi, Springer, Heilderberg, 2010, pp. 389-414.

[6] S. Quintela, M. C. Villarán, I. L. de Armentia and E. Elejalde, "Ochratoxin A Removal in Wine: A Review," Food Control, Vol. 30, No. 2, 2013, pp. 439-445.

[7] L. Covarelli, G. Beccari, A. Marini and L. Tosi, "A Review on the Occurrence and Control of Ochratoxigenic Fungal Species and Ochratoxin A in Dehydrated Grapes, Non-Fortified Dessert Wines and Dried Vine Fruit in the Mediterranean Area," Food Control, Vol. 26, No. 2, 2012, pp. 347-356. doi:10.1016/j.foodcont.2012.01.044

[8] M. F. Terra, G. Prado, G. E. Pereira, H. J. Ematné and L. R. Batista, "Detection of Ochratoxin A in Tropical Wine and Grape Juice from Brazil," Journal of the Science of Food and Agriculture, Vol. 93, No. 4, 2013, pp. 890-894.

[9] F. Karbancıoğlu-Güler and D. Heperkan, "Natural Occurrence of Ochratoxin A in Dried Figs," Analytica Chimica Acta, Vol. 617, No. 1-2, 2008, pp. 32-36. doi:10.1016/j.aca.2008.01.009

[10] D. Ringot, A. Chango, Y.-J. Schneider and Y. Larondelle,
"Toxicokinetics and Toxicodynamics of Ochratoxin A, an Update," Chemico-Biological Interactions, Vol. 159, No. 1, 2006, pp. 18-46. doi:10.1016/j.cbi.2005.10.106

[11] R. C. Gupta, "Veterinary Toxicology: Basic and Clinical Principles," Elsevier Science, 2007. doi:10.5005/jp/books/10078

[12] C. Zaied, S. Abid, L. Zorgui, C. Bouaziz, S. Chouchane, M. Jomaa, et al., "Natural Occurrence of Ochratoxin A in Tunisian Cereals," Food Control, Vol. 20, No. 3, 2009, pp. 218-222. doi:10.1016/j.foodcont.2008.05.002

[13] S. Amézqueta, E. González-Peñas, M. Murillo-Arbizu and A. L. de Cerain, "Ochratoxin A Decontamination: A Review," Food Control, Vol. 20, No. 4, 2009, pp. 326-333. doi:10.1016/i.foodcont.2008.05.017

[14] S. Abid, W. Hassen, A. Achour, H. Skhiri, K. Maaroufi, F. Ellouz, et al., "Ochratoxin a and Human Chronic Nephropathy in Tunisia: Is the Situation Endemic?" Human \& Experimental Toxicology, Vol. 22, No. 2, 2003, pp. 7784. doi:10.1191/0960327103ht3280a

[15] P. B. Wangikar, P. Dwivedi, N. Sinha, A. K. Sharma and A. G. Telang, "Teratogenic Effects in Rabbits of Simultaneous Exposure to Ochratoxin A and Aflatoxin B1 with Special Reference to Microscopic Effects," Toxicology, Vol. 215, No. 1-2, 2005, pp. 37-47. doi:10.1016/j.tox.2005.06.022

[16] L. Álvarez, A. G. Gil, O. Ezpeleta, J. A. García-Jalón and A. L. de Cerain, "Immunotoxic Effects of Ochratoxin A in Wistar Rats after Oral Administration," Food and Chemical Toxicology, Vol. 42, No. 5, 2004, pp. 825-834. doi:10.1016/i.fct.2004.01.005

[17] E. E. Creppy, "Update of Survey, Regulation and Toxic Effects of Mycotoxins in Europe," Toxicology Letters, Vol. 127, No. 1-3, 2002, pp. 19-28. doi:10.1016/S0378-4274(01)00479-9

[18] S. Lebrun and W. Föllmann, "Detection of Ochratoxin A-Induced DNA Damage in MDCK Cells by Alkaline Single Cell Gel Electrophoresis (Comet Assay)," Archives of Toxicology, Vol. 75, No. 11-12, 2002, pp. 734-741. doi:10.1007/s00204-001-0291-9

[19] D. Flajs, A. M. Domijan, D. Ivić, B. Cvjetković and M. Peraica, "ELISA and HPLC Analysis of Ochratoxin A in Red Wines of Croatia," Food Control, Vol. 20, No. 6, 2009, pp. 590-592. doi:10.1016/j.foodcont.2008.08.021

[20] P. Verger, E. Counil, J. Tressou and J. C. Leblanc, "Some Recent Advances in Modelling Dietary Exposure to Ochratoxin A," Food Additives and Contaminants, Vol. 22, Suppl. 1, 2005, pp. 94-98. doi: $10.1080 / 02652030500410281$

[21] A. Pittet and D. Royer, "Rapid, Low Cost Thin-Layer Chromatographic Screening Method for the Detection of Ochratoxin A in Green Coffee at a Control Level of 10 $\mu \mathrm{g} / \mathrm{kg}$," Journal of Agricultural and Food Chemistry, Vol. 50, No. 2, 2001, pp. 243-247. doi:10.1021/jf010867w

[22] P. Varelis, S.-L. L. Leong, A. Hocking and G. Giannikopoulos, "Quantitative Analysis of Ochratoxin A in Wine and Beer Using Solid Phase Extraction and High Performance Liquid Chromatography-Fluorescence Detection," Food Additives and Contaminants, Vol. 23, No. 12, 2006, pp. 1308-1315. doi:10.1080/02652030600838258 
[23] M. Reinsch, A. Töpfer, A. Lehmann, I. Nehls and U. Panne, "Determination of Ochratoxin A in Beer by LCMS/MS Ion Trap Detection," Food Chemistry, Vol. 100, No. 1, 2007, pp. 312-317.

doi:10.1016/j.foodchem.2005.10.005

[24] C. Juan, C. M. Lino, A. Pena, J. C. Moltó, J. Mañes and I. Silveira, "Determination of Ochratoxin A in Maize Bread Samples by LC with Fluorescence Detection," Talanta, Vol. 73, No. 2, 2007, pp. 246-250. doi:10.1016/j.talanta.2007.03.029

[25] D Caputo, G De Cesare, C Fanelli, A Nascetti, A Ricelli, R Scipinotti, Innovative Detection System of Ochratoxin A by Thin Film Photodiodes, Sensors, 7(2007) 1317-22. doi: $10.3390 / \mathrm{s} 7071317$

[26] M. V. Selma, P. V. Martínez-Culebras, R. Aznar, "RealTime PCR Based Procedures for Detection and Quantification of Aspergillus carbonarius in Wine Grapes," International Journal of Food Microbiology, Vol. 122, No. 1-2, 2008, pp. 126-134. doi:10.1016/j.ijfoodmicro.2007.11.049

[27] R. Ghali, K. Hmaissia-khlifa, H. Ghorbel, K. Maaroufi and A. Hedili, "HPLC Determination of Ochratoxin A in High Consumption Tunisian Foods," Food Control, Vol. 20, No. 8, 2009, pp. 716-720. doi:10.1016/j.foodcont.2008.09.004

[28] W. Lai, D. Y. C. Fung, X. Yang, L. Renrong and Y. Xiong, "Development of a Colloidal Gold Strip for Rapid Detection of Ochratoxin A with Mimotope Peptide," Food Control, Vol. 20, No. 9, 2009, pp. 791-795. doi:10.1016/i.foodcont.2008.10.007

[29] T. Hianik, "Biosensors for Detection of Ochratoxin A Portable Chemical Sensors," In: D. P. Nikolelis, Ed., Portable Chemical Sensors: Weapons against Bioterrorism, Springer, Heilderberg, 2012, pp. 193-211.

[30] M. Campas, D. Garibo and B. Prieto-Simon, "Novel Nanobiotechnological Concepts in Electrochemical Biosensors for the Analysis of Toxins," Analyst, Vol. 137, No. 5, 2012, pp. 1055-1067. doi:10.1039/c2an15736e

[31] T. McGrath, C. Elliott and T. Fodey, "Biosensors for the Analysis of Microbiological and Chemical Contaminants in Food," Analytical and Bioanalytical Chemistry, Vol. 403, No. 1, 2012, pp. 75-92. doi:10.1007/s00216-011-5685-9

[32] T. Li, E.-J. Jo and M.-G. Kim, “A Label-Free Fluorescence Immunoassay System for the Sensitive Detection of the Mycotoxin, Ochratoxin A," Chemical Communications, Vol. 48, No. 17, 2012, pp. 2304-2306. doi: $10.1039 / \mathrm{c} 2 \mathrm{cc} 17088 \mathrm{~d}$

[33] W. C. Tsai and C. K. Hsieh, "QCM - Based Immunosensor for the Determination of Ochratoxin A," Analytical Letters, Vol. 40, No. 10, 2007, pp. 1979-1991. doi:10.1080/00032710701484509

[34] N. Adányi, I. A. Levkovets, S. Rodriguez-Gil, A. Ronald, M. Váradi and I. Szendrő, "Development of Immunosensor Based on OWLS Technique for Determining Aflatoxin B1 and Ochratoxin A," Biosensors and Bioelectronics, Vol. 22, No. 6, 2007, pp. 797-802. doi:10.1016/j.bios.2006.02.015

[35] B. Prieto-Simón, M. Campàs, J.-L. Marty and T. Noguer,
"Novel Highly-Performing Immunosensor-Based Strategy for Ochratoxin A Detection in Wine Samples," Biosensors and Bioelectronics, Vol. 23, No. 7, 2008, pp. 995-1002. doi:10.1016/j.bios.2007.10.002

[36] A. A. Ansari, A. Kaushik, P. R. Solanki and B. D. Malhotra, "Nanostructured Zinc Oxide Platform for Mycotoxin Detection," Bioelectrochemistry, Vol. 77, No. 2, 2010, pp. 75-81. doi:10.1016/j.bioelechem.2009.06.014

[37] A. Kaushik, P. R. Solanki, A. A. Ansari, S. Ahmad and B. D. Malhotra, "A Nanostructured Cerium Oxide FilmBased Immunosensor for Mycotoxin Detection," Nanotechnology, Vol. 20, No. 5, 2009, Article ID: 055105. doi:10.1088/0957-4484/20/5/055105

[38] A.-E. Radi, X. Muñoz-Berbel, V. Lates and J.-L. Marty, "Label-Free Impedimetric Immunosensor for Sensitive Detection of Ochratoxin A," Biosensors and Bioelectronics, Vol. 24, No. 7, 2009, pp. 1888-1892. doi:10.1016/j.bios.2008.09.021

[39] A.-E. Radi, X. Muñoz-Berbel, M. Cortina-Puig and J.-L. Marty, "An Electrochemical Immunosensor for Ochratoxin A Based on Immobilization of Antibodies on DiazoniumFunctionalized Gold Electrode," Electrochimica Acta, Vol. 54, No. 8, 2009, pp. 2180-2184. doi:10.1016/j.electacta.2008.10.013

[40] C. Yang, V. Lates, B. Prieto-Simón, J.-L. Marty and X. R. Yang, "Aptamer-DNAzyme Hairpins for Biosensing of Ochratoxin A," Biosensors and Bioelectronics, Vol. 32, No. 1, 2012, pp. 208-212. doi:10.1016/j.bios.2011.12.011

[41] G. Castillo, I. Lamberti, L. Mosiello and T. Hianik, "High-Sensitive Impedimetric Aptasensor for Detection Ochratoxin A in Food Sensors and Microsystems," In: A. D'Amico, C. D. Di Natale, L. Mosiello and G. Zappa Eds., Sensors and Microsystems. Lecture Notes in Electrical Engineering, Springer, Heilderberg, 2012, pp. 31-35.

[42] G. Castillo, I. Lamberti, L. Mosiello and T. Hianik, "Impedimetric DNA Aptasensor for Sensitive Detection of Ochratoxin A in Food," Electroanalysis, Vol. 24, No. 3, 2012, pp. 512-520. doi:10.1002/elan.201100485

[43] J. Vidal, P. Duato, L. Bonel and J. Castillo, "Use of Polyclonal Antibodies to Ochratoxin A with a QuartzCrystal Microbalance for Developing Real-Time Mycotoxin Piezoelectric Immunosensors," Analytical and Bioanalytical Chemistry, Vol. 394, No. 2, 2009, pp. 575-582. doi:10.1007/s00216-009-2736-6

[44] H. Cheap, M. Sanchez, V. Vivier, H. Perrot and J. L. Marty, "Ochratoxin A Detection by an Immunosensor Using Impedance Spectroscopy Coupled with Quartz Crystal Microbalance," Sensor Letters, Vol. 9, No. 6, 2011, pp. 2312-2315. doi:10.1166/s1.2011.1806

[45] X.-P. Liu, Y.-J. Deng, X.-Y. Jin, L.-G. Chen, J.-H. Jiang, G.-L. Shen, et al., "Ultrasensitive Electrochemical Immunosensor for Ochratoxin A Using Gold ColloidMediated Hapten Immobilization," Analytical Biochemistry, Vol. 389, No. 1, 2009, pp. 63-68. doi:10.1016/j.ab.2009.03.019

[46] N. Prabhakar, Z. Matharu and B. D. Malhotra, "Polyaniline Langmuir-Blodgett Film Based Aptasensor for Ochratoxin A Detection," Biosensors and Bioelectronics, Vol. 26, No. 10, 2011, pp. 4006-4011. 
doi:10.1016/j.bios.2011.03.014

[47] L.-G. Zamfir, I. Geana, S. Bourigua, L. Rotariu, C. Bala, A. Errachid, et al., "Highly Sensitive Label-Free Immunosensor for Ochratoxin A Based on Functionalized Magnetic Nanoparticles and EIS/SPR Detection," Sensors and Actuators B: Chemical, Vol. 159, No. 1, 2011, pp. 178-184. doi:10.1016/j.snb.2011.06.069

[48] P. R. Solanki, A. Kaushik, T. Manaka, M. K. Pandey, M. Iwamoto, V. V. Agrawal, et al., "Self-Assembled Monolayer Based Impedimetric Platform for Food Borne Mycotoxin Detection," Nanoscale, Vol. 2, No. 12, 2010, pp. 2811-2817. doi:10.1039/c0nr00289e

[49] H. Ju, X. Zhang and J. Wang, "Nanomaterials for Immunosensors and Immunoassays NanoBiosensing," Springer, New York, 2011, pp. 425-452.

[50] P. R. Solanki, A. Kaushik, V. V. Agrawal and B. D. Malhotra, "Nanostructured Metal Oxide-Based Biosensors," NPG Asia Materials, Vol. 3, No. 1, 2011, pp. 17-24. doi:10.1038/asiamat.2010.137

[51] A. Anees, M. Ansari, M. S. A. Alsalhi and A. S. Aldwayyan, "Nanostructured Metal Oxides Based Enzymatic Electrochemical Biosensors," In: P. A. Serra, Eds., Biosensors, InTech, New York, 2010, pp. 23-46.

[52] A. G. Mamalis, "Recent Advances in Nanotechnology," Journal of Materials Processing Technology, Vol. 181, No. 1-3, 2007, pp. 52-58. doi:10.1016/j.jmatprotec.2006.03.052

[53] P. Pandey, M. Datta and B. D. Malhotra, "Prospects of Nanomaterials in Biosensors," Analytical Letters, Vol. 41, No. 2, 2008, pp. 159-209. doi:10.1080/00032710701792620

[54] B. D. Malhotra, A. Chaubey and S. P. Singh, "Prospects of Conducting Polymers in Biosensors," Analytica Chimica Acta, Vol. 578, No. 1, 2006, pp. 59-74. doi:10.1016/j.aca.2006.04.055

[55] C. Dhand, M. Das, M. Datta and B. D. Malhotra, "Recent Advances in Polyaniline Based Biosensors," Biosensors and Bioelectronics, Vol. 26, No. 6, 2011, pp. 2811-2821. doi:10.1016/j.bios.2010.10.017

[56] Rajesh, T. Ahuja and D. Kumar, "Recent Progress in the Development of Nano-Structured Conducting Polymers/ Nanocomposites for Sensor Applications," Sensors and Actuators B: Chemical, Vol. 136, No. 1, 2009, pp. 275286. doi:10.1016/j.snb.2008.09.014

[57] T. Ahuja, I. A. Mir, D. Kumar and Rajesh, "Biomolecular Immobilization on Conducting Polymers for Biosensing Applications," Biomaterials, Vol. 28, No. 5, 2007, pp. 791-805. doi:10.1016/j.biomaterials.2006.09.046

[58] A. Kaushik, R. Khan, P. R. Solanki, P. Pandey, J. Alam, S. Ahmad, et al., "Iron Oxide Nanoparticles-Chitosan Composite Based Glucose Biosensor," Biosensors and Bioelectronics, Vol. 24, No. 4, 2008, pp. 676-683. doi:10.1016/j.bios.2008.06.032

[59] A. Kaushik, P. R. Solanki, A. A. Ansari, B. D. Malhotra and S. Ahmad, "Iron Oxide-Chitosan Hybrid Nanobiocomposite Based Nucleic Acid Sensor for Pyrethroid Detection," Biochemical Engineering Journal, Vol. 46, No. 2, 2009, pp. 132-140. doi:10.1016/j.bej.2009.04.021
[60] A. Kaushik, P. R. Solanki, A. A. Ansari, G. Sumana, S. Ahmad and B. D. Malhotra, "Iron Oxide-Chitosan Nanobiocomposite for Urea Sensor," Sensors and Actuators B: Chemical, Vol. 138, No. 2, 2009, pp. 572-580. doi:10.1016/j.snb.2009.02.005

[61] A. Kaushik, P. R. Solanki, M. K. Pandey, S. Ahmad and B. D. Malhotra, "Cerium Oxide-Chitosan Based Nanobiocomposite for Food Borne Mycotoxin Detection," Applied Physics Letters, Vol. 95, No. 17, 2009, Article ID: 173703. doi:10.1063/1.3249586

[62] A. Kaushik, P. R. Solanki, M. K. Pandey, K. Kaneto, S. Ahmad and B. D. Malhotra, "Carbon Nanotubes-Chitosan Nanobiocomposite for Immunosensor," Thin Solid Films, Vol. 519, No. 3, 2010, pp. 1160-1166. doi:10.1016/i.tsf.2010.08.062

[63] A. Kaushik, P. R. Solanki, K. N. Sood, S. Ahmad and B. D. Malhotra, "Fumed Silica Nanoparticles-Chitosan Nanobiocomposite for Ochratoxin-A Detection," Electrochemistry Communications, Vol. 11, No. 10, 2009, pp. 1919-1923. doi:10.1016/j.elecom.2009.08.016

[64] S. K. Arya, P. R. Solanki, M. Datta and B. D. Malhotra, "Recent Advances in Self-Assembled Monolayers Based Biomolecular Electronic Devices," Biosensors and Bioelectronics, Vol. 24, No. 9, 2009, pp. 2810-2817. doi:10.1016/j.bios.2009.02.008

[65] P. R. Solanki, A. Kaushik, P. M. Chavhan, S. N. Maheshwari and B. D. Malhotra, "Nanostructured Zirconium Oxide Based Genosensor for Escherichia coli Detection," Electrochemistry Communications, Vol. 11, No. 12, 2009, pp. 2272-2277. doi:10.1016/i.elecom.2009.10.007

[66] A. Kaushik, J. Kumar, M. K. Tiwari, R. Khan, B. D. Malhotra, V. Gupta, et al., "Fabrication and Characterization of Polyaniline-ZnO Hybrid Nanocomposite Thin Films," Journal of Nanoscience and Nanotechnology, Vol. 8, No. 4, 2008, pp. 1757-1761. doi:10.1166/jnn.2008.006

[67] M. Kruk and M. Jaroniec, "Gas Adsorption Characterization of Ordered Organic-Inorganic Nanocomposite Materials," Chemistry of Materials, Vol. 3, No. 10, 2001, pp. 3169-3183. doi:10.1021/cm0101069

[68] D. G. Shchukin, G. B. Sukhorukov and H. Möhwald, "Smart Inorganic/Organic Nanocomposite Hollow Microcapsules," Angewandte Chemie International Edition, Vol. 42, No. 37, 2003, pp. 4472-4475. doi:10.1002/anie. 200352068

[69] E. Ruiz-Hitzky, "Functionalizing Inorganic Solids: Towards Organic-Inorganic Nanostructured Materials for Intelligent and Bioinspired Systems," The Chemical Record, Vol. 3, No. 2, 2003, pp. 88-100. doi: $10.1002 /$ tcr. 10054

[70] B. Krajewska, "Application of Chitin- and ChitosanBased Materials for Enzyme Immobilizations: A Review," Enzyme and Microbial Technology, Vol. 35, No. 2-3, 2004, pp. 126-139. doi:10.1016/j.enzmictec.2003.12.013

[71] E. Ruiz-Hitzky, M. Darder and P. Aranda, "Functional Biopolymer Nanocomposites Based on Layered Solids," Journal of Materials Chemistry, Vol. 15, No. 35-36, 2005, pp. 3650-3662. doi:10.1039/b505640n

[72] H. Uehara, M. Kakiage, M. Sekiya, D. Sakuma, T. Yamonobe, N. Takano, et al., "Size-Selective Diffusion 
in Nanoporous but Flexible Membranes for Glucose Sensors, ACS Nano, Vol. 3, No. 4, 2009, pp. 924-932. doi:10.1021/nn8008728

[73] Z. Burghard, A. Tucic, L. P. H. Jeurgens, R. C. Hoffmann, J. Bill and F. Aldinger, "Nanomechanical Properties of Bioinspired Organic-Inorganic Composite Films," Advanced Materials, Vol. 19, No. 7, 2007, pp. 970-974. doi:10.1002/adma.200601068

[74] D. B. Mitzi, "Thin-Film Deposition of Organic-Inorganic Hybrid Materials," Chemistry of Materials, Vol. 13, No. 10, 2001, pp. 3283-3298. doi:10.1021/cm0101677

[75] C. Sanchez, B. Julian, P. Belleville and M. Popall, "Applications of Hybrid Organic-Inorganic Nanocomposites," Journal of Materials Chemistry, Vol. 15, No. 3536, 2005, pp. 3559-3592. doi:10.1039/b509097k

[76] Y. A. Shchipunov, T. Y. Y. Karpenko and A. V. Krekoten, "Hybrid Organic-Inorganic Nanocomposites Fabricated with a Novel Biocompatible Precursor Using Sol-Gel Processing," Composite Interfaces, Vol. 11, No. 8-9, 2005, pp. 587-607. doi:10.1163/1568554053148816

[77] J.-L. Shi, Z.-L. Hua and L.-X. Zhang, "Nanocomposites from Ordered Mesoporous Materials," Journal of Materials Chemistry, Vol. 14, No. 5, 2004, pp. 795-806. doi:10.1039/b315861f

[78] N. Sukpirom and M. M. Lerner, "Preparation of OrganicInorganic Nanocomposites with a Layered Titanate," Chemistry of Materials, Vol. 13, No. 6, 2001, pp. 21792185. doi: $10.1021 / \mathrm{cm} 0101226$

[79] A. Walcarius, "Electrochemical Applications of SilicaBased Organic-Inorganic Hybrid Materials," Chemistry of Materials, Vol. 13, No. 10, 2001, pp. 3351-3372. doi: $10.1021 / \mathrm{cm} 0110167$

[80] L. Chen and W. Gorski, "Bioinorganic Composites for Enzyme Electrodes," Analytical Chemistry, Vol. 73, No. 13, 2001, pp. 2862-2868. doi:10.1021/ac010009z

[81] J. Li, Q. Liu, Y. Liu, S. Liu and S. Yao, "DNA Biosensor Based on Chitosan Film Doped with Carbon Nanotubes," Analytical Biochemistry, Vol. 346, No. 1, 2005, pp. 107114. doi:10.1016/j.ab.2005.07.037

[82] D. J. Macquarrie and J. J. E. Hardy, "Applications of Functionalized Chitosan in Catalysis," Industrial \& Engineering Chemistry Research, Vol. 44, No. 23, 2005, pp. 8499-8520. doi:10.1021/ie050007v

[83] D. Odaci, S. Timur and A. Telefoncu, "Bacterial Sensors Based on Chitosan Matrices," Sensors and Actuators B: Chemical, Vol. 134, No. 1, 2008, pp. 89-94. doi:10.1016/j.snb.2008.04.013

[84] H. Yi, L.-Q. Wu, W. E. Bentley, R. Ghodssi, G. W. Rubloff, J. N. Culver, et al., "Biofabrication with Chitosan," Biomacromolecules, Vol. 6, No. 6, 2005, pp. 28812894. doi: $10.1021 / \mathrm{bm} 0504101$

[85] J. M. C. S. Magalhães and A. A. S. C. Machado, "Urea Potentiometric Biosensor Based on Urease Immobilized on Chitosan Membranes," Talanta, Vol. 47, No. 1, 1998, pp. 183-191. doi:10.1016/S0039-9140(98)00066-6
[86] J. Cruz, M. Kawasaki and W. Gorski, "Electrode Coatings Based on Chitosan Scaffolds," Analytical Chemistry, Vol. 72, No. 4, 2000, pp. 680-686. doi:10.1021/ac990954b

[87] Y. Miao and S. N. Tan, "Amperometric Hydrogen Peroxide Biosensor Based on Immobilization of Peroxidase in Chitosan Matrix Crosslinked with Glutaraldehyde," Analyst, Vol. 125, No. 9, 2000, pp. 1591-1594. doi: $10.1039 / \mathrm{b} 003483 \mathrm{p}$

[88] C. Xu, H. Cai, P. G. He and Y. Z. Fang, "Electrochemical Detection of Sequence-Specific DNA Using a DNA Probe Labeled with Aminoferrocene and Chitosan Modified Electrode Immobilized with ssDNA," Analyst, Vol. 126, No. 1, 2001, pp. 62-65. doi:10.1039/b005847p

[89] H. Gupta and M. Aqil, "Contact Lenses in Ocular Therapeutics," Drug Discovery Today, Vol. 17, No. 9-10, 2012, pp. 522-527. doi:10.1016/j.drudis.2012.01.014

[90] M. Garcia-Fuentes and M. J. Alonso, "Chitosan-Based Drug Nanocarriers: Where Do We Stand?" Journal of Controlled Release, Vol. 161, No. 2, 2012, pp. 496-504. doi:10.1016/i.jconrel.2012.03.017

[91] C. A. Custódio, C. M. Alves, R. L. Reis and J. F. Mano, "Immobilization of Fibronectin in Chitosan Substrates Improves Cell Adhesion and Proliferation," Journal of Tissue Engineering and Regenerative Medicine, Vol. 4, No. 4, 2010, pp. 316-323. doi:10.1002/term.248

[92] I. T. Cavalcanti, B. V. M. Silva, N. G. Peres, P. Moura, M. D. P. T. Sotomayor, M. I. F. Guedes, et al., "A Disposable Chitosan-Modified Carbon Fiber Electrode for Dengue Virus Envelope Protein Detection," Talanta, Vol. 91, No. 15, 2012, pp. 41-46. doi:10.1016/j.talanta.2012.01.002

[93] S. Parvez, M. Rahman, M. Khan, M. Khan, J. Islam, M. Ahmed, et al., "Preparation and Characterization of Artificial Skin Using Chitosan and Gelatin Composites for Potential Biomedical Application," Polymer Bulletin, Vol. 69, No. 6, 2012, pp. 715-731. doi:10.1007/s00289-012-0761-7

[94] L. Upadhyaya, J. Singh, V. Agarwal and R. P. Tewari, "Biomedical Applications of Carboxymethyl Chitosans," Carbohydrate Polymers, Vol. 91, No. 1, 2013, pp. 452466.

[95] R. Khan and M. Dhayal, "Nanocrystalline Bioactive $\mathrm{TiO}_{2}$ Chitosan Impedimetric Immunosensor for Ochratoxin-A," Electrochemistry Communications, Vol. 10, No. 3, 2008 , pp. 492-495. doi:10.1016/j.elecom.2008.01.013

[96] R. Khan and M. Dhayal, "Chitosan/Polyaniline Hybrid Conducting Biopolymer Base Impedimetric Immunosensor to Detect Ochratoxin-A," Biosensors and Bioelectronics, Vol. 24, No. 6, 2009, pp. 1700-1705. doi:10.1016/i.bios.2008.08.046

[97] A. Kaushik, P. R. Solanki, A. A. Ansari, S. Ahmad and B. D. Malhotra, "Chitosan-Iron Oxide Nanobiocomposite Based Immunosensor for Ochratoxin-A," Electrochemistry Communications, Vol. 10, No. 9, 2008, pp. 1364-1368. doi:10.1016/i.elecom.2008.07.007 